\title{
URGENSI PENDIDIKAN AKHLAK DI USIA DINI
}

\author{
Zubairi Muzakki ${ }^{1}$ \\ zubairimuzakki@gmail.com
}

\section{الخلاصة}

ترقية أخلاق الأو لاد تدلُّ علي عمليَّة التربية الإسلامية في حياة الأو لاد.

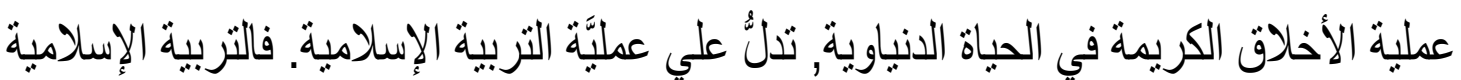

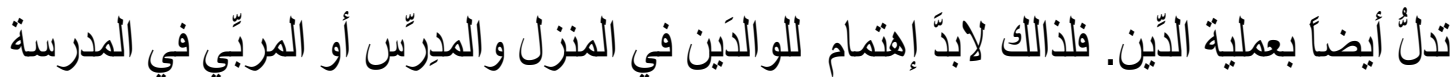

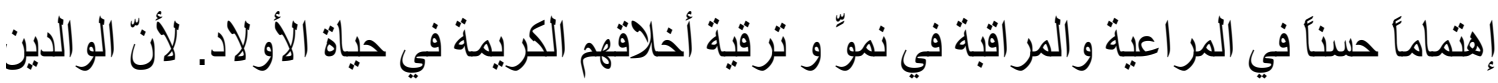

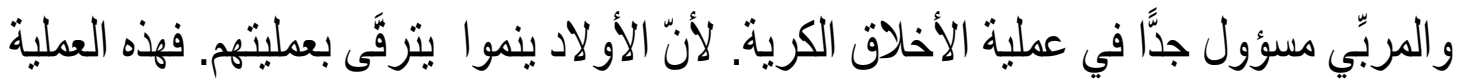

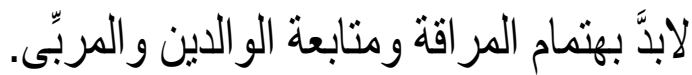

\section{Pendahuluan}

Pendidikan akhlaq anak pada usia dini sangatlah penting dan mendasar, untuk memperkokoh pondasi-pondasi budipekerti, etika dan nilai-nilai islami. Hal ini sudah harus dimulai dan dibiasakan sejak dini melalui kebiasaan dirumah bersama orang tua keluarga dan lingkungan sekitar, serta proses pendidikan karakter di sekolah.

Dalam pandangan para peneliti anak, bahwa anak adalah anugrah dari Allah yang sangat dinanti oleh sebuah keluarga karena seorang anak adalah harta yang sangat tidak ternilai harganya, selain itu anak juga merupakan sebuah amanah dari Allah yang di titipkan kepada orang tua untuk dijaga, dididik, dan juga diberikan kasih sayang. Sedangkan dalam pandangan yang lain bahwa anak merupakan rahmat serta anugrah yang diberikan oleh Allah sebagai penguji keimanan, dan juga sebagi sebuah media beramal yang dijadikan bekal untuk di akhirat, dan anak juga sebagai tempat bergantung ketika usia senja, dan juga makhluk yang wajib didik".

\footnotetext{
${ }^{1}$ Dosen Tetap Prodi PAI STAI Asy-Syukriyyah
} 


\section{Jurnal Asy-Syukriyyah}

Dengan beberapa pandangan tersebut, maka sebagai bentuk pengejawantahan dari amanah dan tanggungjawab terhadap anak, maka orang tua dan guru harus bekerjasama untuk menjalankan amanah dan menghantarkan anak agar menjadi anak yang berakhlaq mulia, oleh karena itu sangatlah menarik untuk dikaji dalam jurnal ini dengan beberapa rumusan kajian Bagaimana Pandangan Al-Quran dan Al-Hadist tentang pendidikan anak usia dini, seperti apa pendidikan anak usia dini di Sekolah dan lingkungan keluarga,dan seberapa penting pendidikan akhlak anak usia dini bagi orang tua.?

Dengan rumusan tersebut, diharapkan dapat mengasilkan jawaban konkrit bagi pihak sekolah dan orang tua dalam membina dan mendidik anak dengan nilai-nilai akhlaq sejak dini, sehingga dapat membentuk generasi-generasi yang berakhlak dan berkarakter islami.

\section{Pembahasan}

Pendidikan akhlak sebagai suatu proses pengembangan potensi spiritual dan emosional anak pada usia dini, bertujuan untuk mewujudkan manusia yang berilmu, beriman, beramal dan bertakwa kepada Allah SWT, memiliki etos kerja yang tinggi berbudi pekerti luhur, mandiri dan bertanggung jawab terhadap dirinya, bangsa, dan negara serta agama. Dalam Islam manusia mempunyai kemampuan dasar yang disebut dengan "fitrah". Secara epistimologis "fitrah" berarti "sifat asal, kesucian, bakat, dan pembawaan". Secara terminologi, Muhammad al-Jurjani menyebutkan, bahwa "fitrah" adalah: Tabiat yang siap menerima agama Islam. Pendidikan akhlak adalah upaya seseorang untuk mengembangkan potensi tauhid agar dapat mewarnai kualitas kehidupan pribadi seseorang.

Rasulullah Muhammad SAW Bersabda :

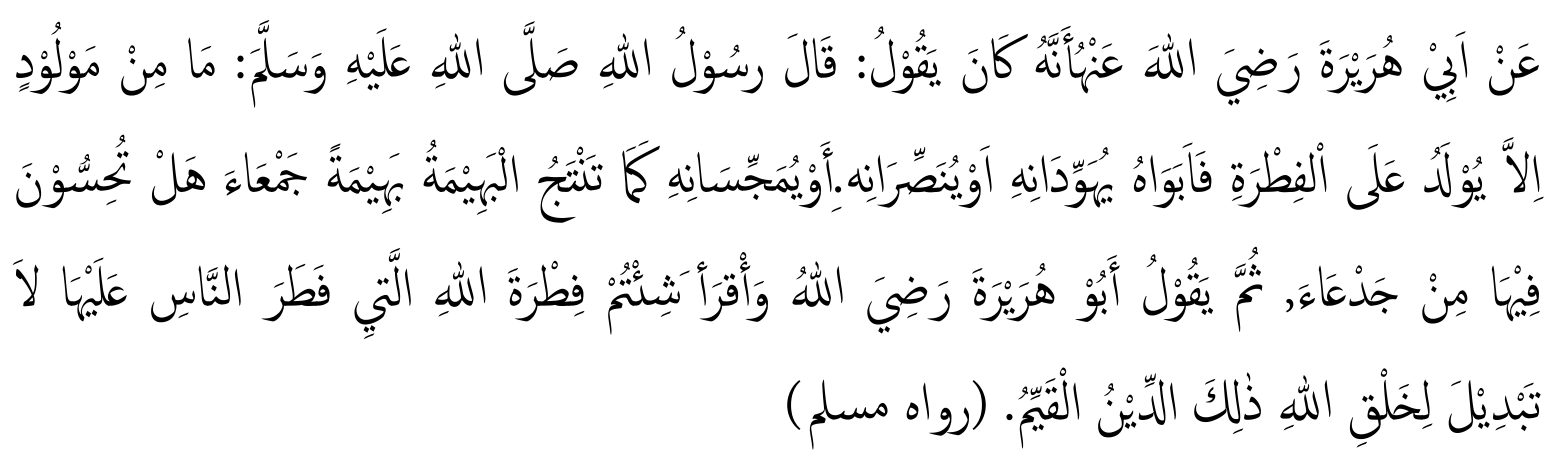


"Diriwayatkan dari Abu Hurairah r.a. sesungguhnya abi Hurairah Mengucapkan: Rasulullah Saw. pernah bersabda "Setiap anak dilahirkan dalam keadaan fithrah (keimanan terhadap tauhid [tidak mempersekutukan Allah]) tetapi orang tuanyalah menjadikan dia seorang Yahudi atau Nasrani atau Majusi sebagaimana seekor hewan melahirkan seekor hewan yang sempurna. Apakah kau melihatnya buntung? "Kemudian Abu Hurairah membacakan ayat-ayat suci ini: (Tetaplah atas) fitrah manusia menurut fitrah itu. (Hukum - hukum) ciptaan Allah tidak dapat diubah.Itulah agama yang benar.Tetapi sebagian manusia tidak mengetahui.” (H.R. Muslim).

Tujuan pendidikan akhlak atau Agama Islam adalah idealitas (cita-cita) yang mengandung nilai Islam yang hendak dicapai dalam proses pendidikan Islam berdasarkan ajaran Islam secara bertahap. ${ }^{2}$

Berdasarkan pengertian di atas dapat diambil kesimpulan bahwa pendidikan akhlak yaitu sebuah proses yang dilakukan untuk menciptakan manusia-manusia seutuhnya, berilmu, beramal, beriman dan bertakwa kepada Allah SWT, serta mampu mewujudkan eksistensinya sebagai khalifah Allah SWT di muka bumi, yang berdasarkan ajaran Al-Qur'an dan Al-Sunnah. Ketika hal ini dapat dicapai, dalam konteks ini berarti menurut Imam Al-Ghazali dapat tercipta insan kamil.

Terwujudnya nilai-nilai luhur berupa Ilahiyah, kerohanian, kemanusiaan, kemasyarakatan, kepribadian, kebangsaan, pengetahuan dan ketrampilan.Untuk mempersiapkan peserta didik yang handal diperlukan nilai-nilai Islami yang mengarah pada kualitas hidup di masa mendatang.Namun hal ini tidak terlepas dari implementasi dari akhlaq sebagai penggerak dari semua nilai-nilai yang ada. Maka dari itu untuk penulis mencoba untuk menguraikan beberapa hal yang berkaitan dengan akhlaq, antara lain;

\section{Hakekat Akhlaq Karimah}

Secara etimologis, akhlak berasal dari bahasa Arab yang berarti;

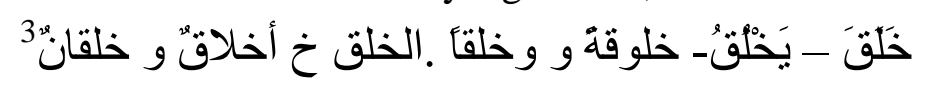

\footnotetext{
${ }^{2}$ Haidar Putra Dauly, Pendidikan Islam dalam Sistem Pendidikan Nasional, Jakarta: Rineka Cipta, 2003.
}

$$
\text { 3/المنجد في اللغة والأعلام. دار المشرق- بيروت الطبعة الخامسة وثلاثون }
$$




\section{Jurnal Asy-Syukriyyah}

Sementara kata khuluk memiliki arti budi pekerti, perangai, tingkah laku atau tabiat". ${ }^{4}$ Setiap manusia dilahirkan dengan tabiat dasarnya yang dibawa dariTuhan, yaitu berupa fitrah.

Secara terminologi Imam al-Ghazali mendefinisikan tentang akhlaq sebagai berkut:

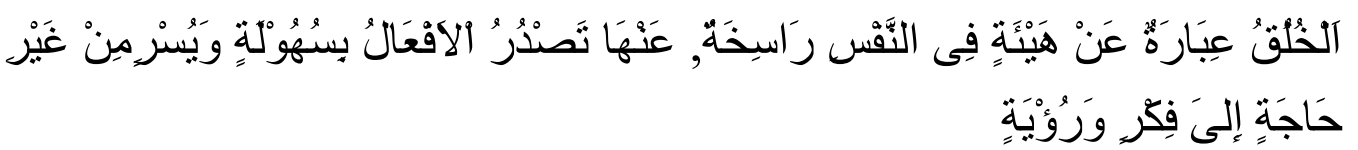

"Akhlak adalah sifat yang tertanam dalam jiwa yang menimbulkan perbuatan-perbuatan dengan gampang dan mudah, tanpa memerlukan pemikiran dan pertimbangan".

Sementara menurut Ibrahim Anis mendefinisikan tentang akhlaqsebagai berikut:

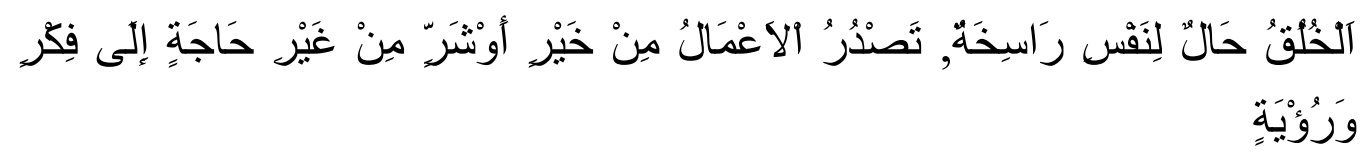

"Akhlaq adalah sifat yang tertanam dalam jiwa, yang dengannya lahirlah macam-macam perbuatan, baik atau buruk, tanpa membutuhkan pemikiran dan pertimbangan ",

Dari kedua definisi di atas dapat disimpulkan bahwa akhlak adalah sifat yang tertanam dalam jiwa manusia, sehingga dia akan muncul secara spontan, tanpa memerlukan pemikiran dan pertimbangan lebih dulu, serta tidak memerlukan dorongan dari luar.

Akhlak juga merupakan suatu tatanan hidup yang membedakan manusia dengan makhluk lainnya, manusia tanpa akhlak akan kehilangan derajat kemanusiaannya sebagai makhluk Allah SWT yang paling mulia, bahkan lebih jelek derajatnya daripada binatang. Sebagai umat Islam tentunya kita dituntut untuk

${ }^{4}$ A. Rohman Ritonga, Akhlak Merakit Hubungan Dengan Sesama Manusia, Cet. I, Surabaya : Amalia, 2005. hal. 7

${ }^{5}$ Yunahar Ilyas, Kuliah Akhlak, cet. VI, Yogyakarta: Pustaka Pelajar Offset, 2004, h. 1-2 
memiliki akhlak Tauhid yang bersumber kepada Al-Qur'an dan Al-Hadits, bukan kepada akhlak seluler yang senantiasa melandaskan sikap hidup yang berorientasi duniawi belaka. $^{6}$

Akhlak karimah merupakan perilaku keagamaan yang memiliki arti "pengabdian terhadap agama atau kesalehan", sementara dalam pendapat yang lain bahwa Akhlaqkarimah adalah "bentuk kesadaran seseorang dalam melaksanakan perintah agama".

Dalam bahasa Inggris kata Akhlaq karimah merupakan kepribadian atau personality yang berasal dari kata persona, yang berarti kedok atau topeng, yaitu tutup muka yang sering dipakai oleh pemain-pemain panggung, yang mempunyai maksud untuk menggambarkan perilaku,watak, atau pribadi seseorang

Sementara ada pendapat bahwa sebenarnya manusia itu di dalam kehidupan sehari-hari tidak selalu membawakan dirinya sebagaimana adanya, melainkan selalu menggunakan tutup muka, maksudnya adalah untuk menutupi kelemahannya, atau ciricirinya yang khas supaya tindakannya dapat diterima oleh masyarakatnya.

Dalam kehidupan sehari-hari di tengah masyarakat, kebanyakan orang hanya akan menunjukkan keadaannya yang baik-baik saja maka untuk itulah dipakailah topen, atau pesona itu. Dengan topeng itu kadang orang-orang akan mendapatkan kedudukan, penghasilan atau prestasi yang lebih daripada bila tanpa topeng.sekalipun ia terpaksa ia harus bertindak, berbicara, atau berbuat yang bukan saja tidak sesuai dengan dirinya sendiri, melainkan kadang-kadang sama sekali bertentangan hakekat kepribadiannya sendiri.

Taat pada agama berarti tunduk dan patuh terhadap segala peraturan agama dan mengamalkannya dalam kehidupan sehari-hari apa yang diperintahkan dan menjauhinya segala apa yang dilarang oleh agama. Sikap Akhlaqkarimah ini perlu ditanamkan kepada anak mulai sejak dini mulai dari pembiasaan oleh orang tua dalam keluarga sampai pada sekolah-sekolah dimana anak itu menuntut pengetahuan. Jika pada diri anak itu telah tertanam sikap religius yang baik, maka ia akan selalu berhubungan

\footnotetext{
${ }^{6}$ Mulyadi. Masam Alfat, Aqidah Akhlak, Semarang: PT. Karya Toha Putra, 1997, hal. 9

${ }^{7}$ Poerwadarminto.1976. Kamus Umum Bahasa Indonesia. Jakarta: Balai Pustaka. Hal 944
} 


\section{Jurnal Asy-Syukriyyah}

dengan Allah senantiasa terikat kepada-Nya. Hatinya penuh ketenangan dan keyakinan, dan ia merasakan bahwa hidup didunia ini bukan sendirian, tetapi ia selalu didampingi oleh zat yang memberi kekuatan dan kekuasaan.

Seorang anak yang berbakti kepada Allah maka ia akan selalu mendekatkan diri kepada-Nya mengerjakan segala perintahnya dan menjauhi segala larangan-Nya.Ia tidak akan melampaui batas dan tidak terlalu mementingkan dunia atas akhirat, juga akhirat atas dunia.

\section{Konsep Akhlaq karimah dalam agama Islam}

Agama menurut pendapat Muhaimin adalah "jalan hidup, atau jalan yang harus ditempuh oleh manusia dalam hidup dan perikehidupannya di dunia, untuk mewujudkan kehidupan yang aman, tenteram dan sejahtera". 8

Berdasarkan pengertian istilah diatas dapat ditarik suatu kesimpulan bahwa kesadaran beragama berati keinsyafan dalam mematuhi dan melaksanakan ajaran Islam secara baik dan disiplin dengan hanya menghambakan diri kepada Allah semata selaku penciptanya sehingga terwujud kehidupan yang aman, tentram dan sejahtera.

Adanya penghambaan diri kepada Allah SWT dengan melaksanakan segala perintah dan menjauhi segala larangan-Nya merupakan suatu kewajiban yang harus dilaksanakan.Sedangkan dalam surat Ali-Imran ayat 102 :

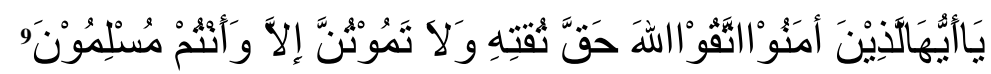

"Hai orang-orang yang beriman, bertakwalah kepada Allah sebenar-benar takwa kepada-Nya dan sekali-kali kamu mati melainkan dalam keadaan beragama Islam" (QS. Ali-Imran : 102).

\footnotetext{
${ }^{8}$ Muhaimin. Dimensi-dimensi Studi Islam.(Surabaya: Karya Abd. Tama. 1994). Hal 32

${ }^{9}$ Dalam Tafsier al-Qurthubi dijelaskan sebagai berikut:

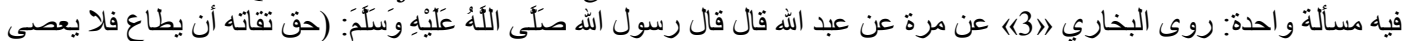

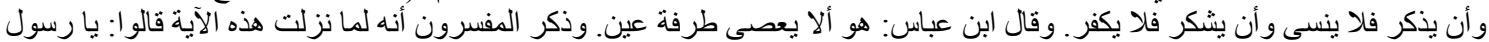

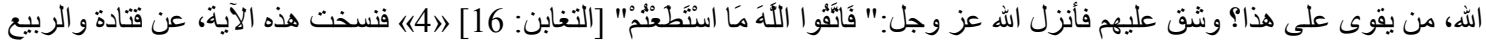

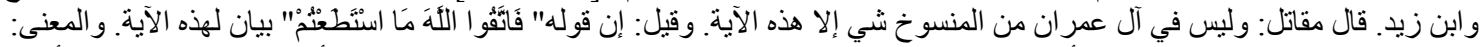

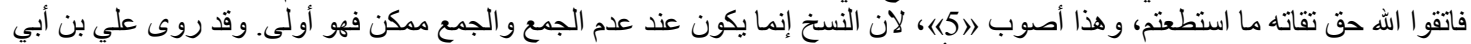

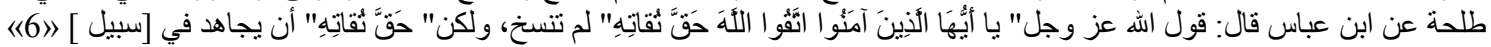




\section{Jurnal Asy-Syukriyyah}

Dari uraian diatas, cukup jelas kiranya bahwa Allah SWT menciptakan manusia dengan tujuan agar manusia semata-mata menyembah dan mengabdi kepadaNya dengan menjalankan segala perintah-Nya dan menjauhi segala larangan-Nya. Melalui risalah yang dibawa oleh Rasulullah SAW yaitu al-qur'an dan al-hadist, sehingga kita mati dan berserah diri kepada Allah sebagai muslim.

Dalam tafsir Al-Mishbah dijelaskan, banhwa untuk menjamin tidak terulangnya peristiwa diatas, serta membentengi kaum muslimin dari maker dan tipu daya lawan, maka orang-orang yang beriman diberi petunjuk oleh lanjutan ayat diatas, yakni firman-Nya: Bertaqwalah kepada Allah sebenar-benarnya taqwa kepadaNya;jauhi seluruh larangan-Nya dan Ikuti seluruh perintah-Nya, sampai pada batas akhir kemampuanmu, dan janganlah sekali-kali kamu mati melainkan dalam keadaan berserah diri kepada Allah, yakni memeluk agama Islam.

Sementara sahabat Nabi saw, memahami Haqqo tuqatih dalam arti menaati Allah dan tidak sekalipun durhaka, mengingat-Nya dan tidak seat pun lupa, serta mensyukuri nikmat-Nya. Demikian penafsiran sahabat Nabi saw., 'Abdullah Ibn Mas'ud. ${ }^{10}$

Sementara dalam sebuah riwayat Ahmad Ibn Hambal dijelaskan;

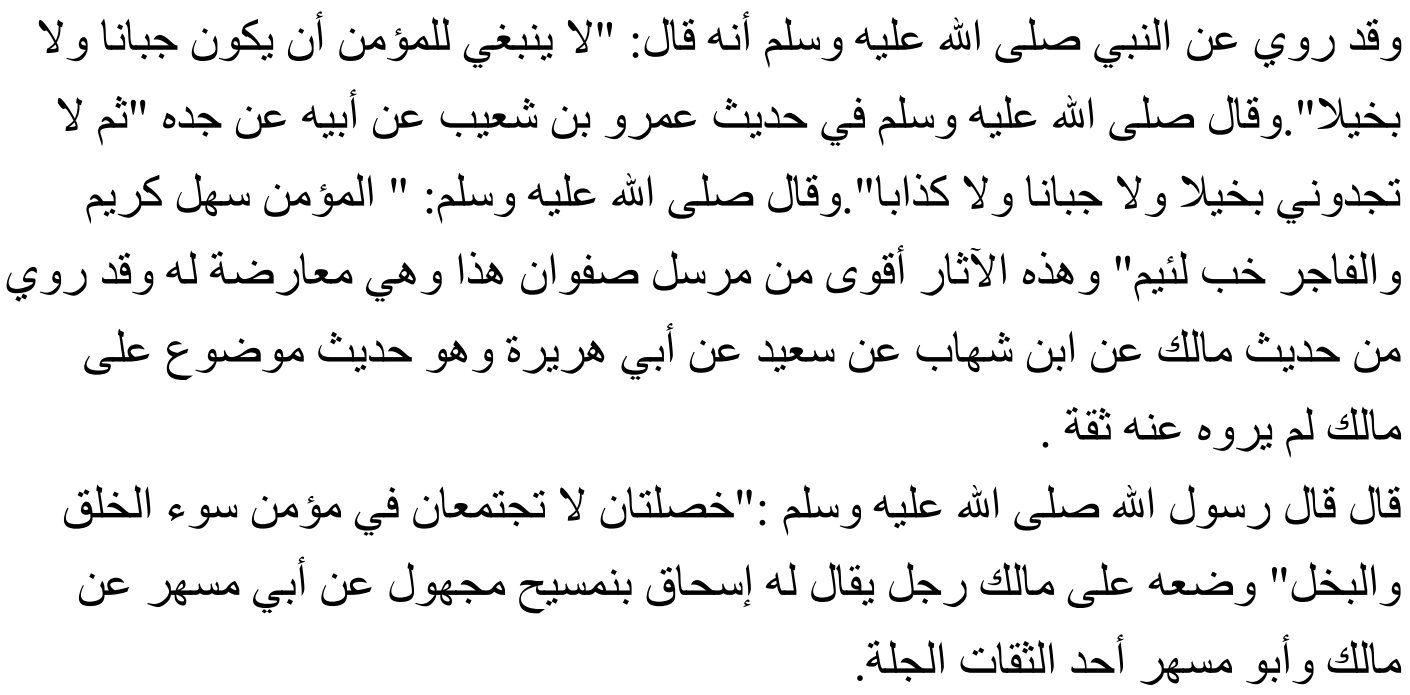

${ }^{10}$ M. Quaish Shihab, Tafsir Al-Mishbah, Volume. 2, Jakarta: Penerbit Lentera Hati, 2007 Cet. X, hal, 167 
وقال أحمد بن حنبل سمعت المعافي بن عمر ان يقول سمعت سفيان الثوري يقول سمعت منصور ا يقول سمعت إبر اهيم يقول وذكر عنده البخل فقال قال رسول الله صلى الله عليه وسلم: "إنما بعثت لأتمم مكارم الأخلاق" وقال رسول الله صلى الله عليه وسلم: " أبي داء أدوى من البخل".

a. Sumber Akhlaq

Dasar atau sumber akhlak adalah Al Qur'an dan Hadits, ${ }^{12}$ dan bukan akal pikiran atau pandangan masyarakat sebagaimana pada konsep etika danmoral.Dalam konsep akhlak, segala sesuatu itu dinilai baik atau buruk, terpuji atau tercela, semata-mata karena syara' (Al-Qur'an dan Hadits).

Imam Ali berkata bahwa akhlak yang baik adalah sebaik-baik teman dan tanda seorang mukmin adalah akhlaknya yang baik. Berikutnya Imam Ja'far AsShadiq juga berkata bahwa barang siapa yang buruk akhlaknya maka tawar jiwanya. ${ }^{13}$

Al Qur'an membahas semua nilai-nilai akhlak tanpa terkecuali.Ayatayatnya tidak meninggalkan satupun permasalahan mengenai akhlak.Setiap dimensi yang berkaitan dengan akhlak terdapat didalamnya baik berupa perintah, larangan maupun berbentuk anjuran baik mengenai akhlak terpuji maupun mengenai perilaku yang tercela. ${ }^{14}$

Dalam ayat suci al-Qur'an yang dijadikan sebagai dasar akhlak, dijelaskan:Q.S. al-Ahzab : 21

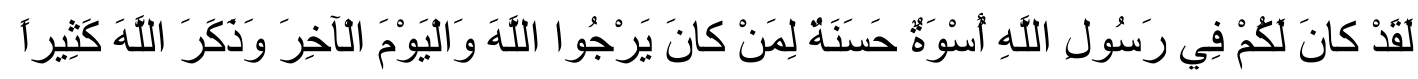

"Sesungguhnya telah ada pada (diri) Rasulullah itu suri teladan yang baik bagimu (yaitu) bagi orang yang mengharap (rahmat) Allah dan (kedatangan) hari kiamat dan dia banyak menyebut Allah ",15

${ }^{12}$ Sulaiman, Akhlak Tauhid, Jilid I, Jakarta : PT. Karya Uni Press, 2001, hal. 8

${ }^{13}$ Khalil Al-Musawi, Bagaimana Membangun Kepribadian Anda, Cet. IV, Jakarta : Lentera, 2000, h. 21

${ }^{14}$ Ali Abdul Halim Mahmud, Akhlak Mulia, Jakarta : Gema Insani, 2004, h.

${ }^{15}$ Ayat ini juga dijelaskan dalam Tafsier Al-Qurthuby; 


\section{Jurnal Asy-Syukriyyah}

Dari penjelasan diatas dijelaskan bahwa, sebaik-baik akhlaq adalah keteladanan dan diteladani serta segala perilaku baik dan berdampak kebaikan bagi orang lain.

b. Fungsi Agama dalam Pembentukan Akhlaq

Dalam perjalanan hidup manusia di muka bumi ini tidak terlepas dari kehendak dan ketentuan Allah SWT, oleh karena itu manusia sebagai hamba Allah SWT harus mendekatkan diri kepada-Nya melalui beragama dengan melaksanakan semua perintah Allah SWT dan menjauhi semua larangan-Nya.

Sekurang-kurangnya ada tiga alasan yang melatar belakangi perlunya manusia terhadap agama. Ketiga alasan tersebut adalah sebagai berikut :

1) Latar Belakang Fitrah Manusia.

Para nabi diutus mngingatkan manusia kepada perjanjian yang telah diikat oleh fitrah mereka, yang kelak mereka akan dituntut untuk memenuhinya. Perjanjian itu tidak tercatat di atas kertas, tidak pula diucapkan oleh lidah, melainkan terukir dengan pena ciptaan Allah di permukaan qalbu

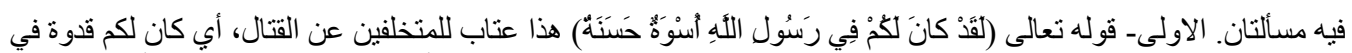

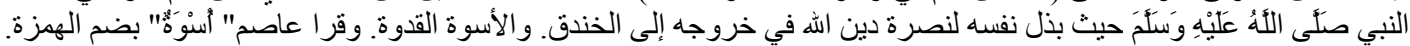

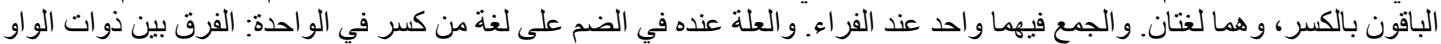

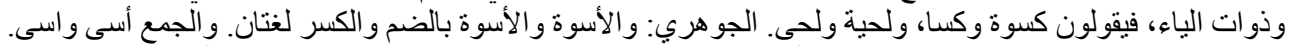

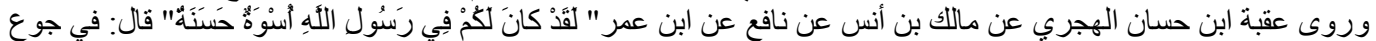

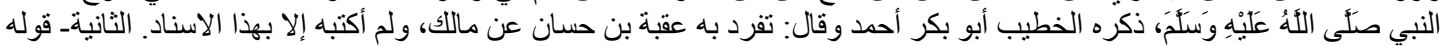

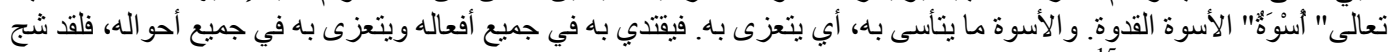
وجهه، وكسرت رباعيته، 15

Hal ini juga diperkuat oleh Hadis riwayat Abu Hurairah;

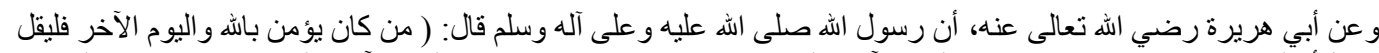

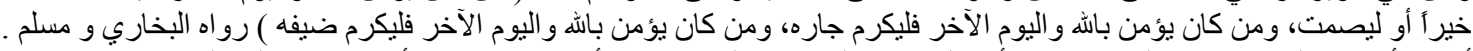

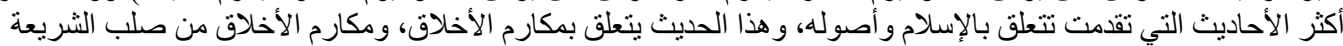

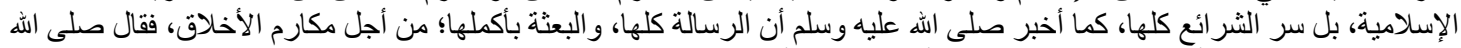

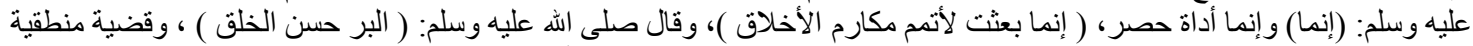

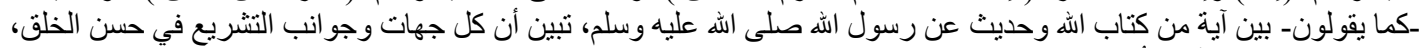

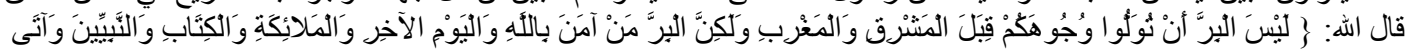

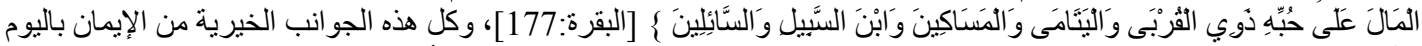

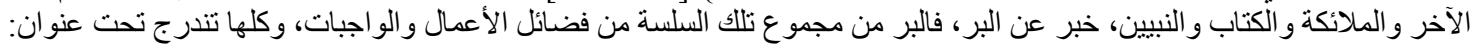

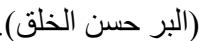

إذأ: حسن الخلق هو البر، و البر هو كل الخصال الكريمة التي قد تكون أصو لا أو فروعأ.15 


\section{Jurnal Asy-Syukriyyah}

dan lubuk fitrah mansia, dan atas permukaan hati nurani serta di kedalaman perasaan batiniyah.

Kenyataan bahwa manusia memiliki fitrah keagamaan tersebut di atas, buat pertama kali ditegaskan dalam ajaran Islam, yakni bahwa agama adalah kebutuhan fitri manusi. Sebelumnya manusia mengenal kenyataan ini. Baru di masa akhir-akhir ini, muncul beberapa orang yang menyerukan dan mempopulerkannya. Fitrah keagamaan yang ada dalam diri manusia inilah yang melatar belakangi perlunya manusia pada agama. Oleh karenanya ketika dating wahyu tuhan yang menyeru mansia agar beragama, maka seruan tersebut memang amat sejalan dengan fitrahnya itu. Dengan jelas bahwa manusia secara fitri merupakan makhluk yang memiliki kemampuan untuk beragama. Hal demikian sejalan dengan petunujuk nabi dalam salah satu hadistnya yang mengatakan bahwa setiap anak yang dilahirkan memiliki fitrah (potensi beragama), maka kedua orang tuanyalah yang menjadikan nak tersebut menjadi yahudi, nasrani atau majusi.

Karena dimiliki petingnya menumbuh kembangkan dan memelihara potensi keagamaan yang ada dalam diri manusia, maka pada saat kelahirannya yang pertama kali diperdengarkan kepada manusia adalah nama Allah dengan cara memperdengarkan suara keadaan dekian dipupuk dengan cara memberikan nam yang baik, karena nama yang baik mendoakan kepada orang yang dinamainya.

Selanjutnya diberikan makanan yang bersih dan suci yang dilambangkan dengan memberi madu pada saat kelahiran anak, dicukur rambutnya dengan tujuan agar menyukai kebersihan, keindahan dan ketampanan yang semuanya itu disukai Allah.Selanjunya dipotongkan hewan aqiqoh yang dihidangkan kepada tetangga dan karib kerabat dengan maksud untuk mengakui eksistensi anak tersebut di tengah-tengah lingkungan keluarganya yang selanjutnya dapat menumbuhkan rasa harga dirinya. ${ }^{16}$

\footnotetext{
${ }^{16}$ Abuddin Nata, Manajemen Pendidikan, (Jakarta: Prenada Media.2003) Hal 21
} 
2) Kelemahan dan Kekurangan Manusia

Faktor lainnya yang melatar belakangi manusia memerlukan agama adalah karena disamping manusia memiliki kesempurnaan juga memiliki kekurangan. Hal ini antara lain diungkapkan oleh kata al-nafs. Dalam pandangan Al-Qur'an nafs diciptakan Allah dalam kedaan sempurna untuk berfungsi menampung serta mendoronga mansuia berbuat kebaikan dan keburukan, dan karena itu sisi dalam manusia inilah yang oleh al-qur'an dianjurkan untuk diberi perhatian lebih besar. Kita misalnya membaca ayat yang berbunyi :

\section{وَنَقَس وَمَا سَوَّاهَا. فَأَلْهَهَهَا فُجُوْرَهَا وَتَقَوَاهَا}

"Demi nafs serta penyempurnaan ciptaan, Allah mengilhamkan kepadanya kefasikan dan ketakwaan” (QS. Al-Syams, 91:7-8).

Menurut Quraish Shihab dalam Tafsier Al-Mishbah, bahwa kata mengilhamkan berarti potensi agar manusia melalui nafs menangkap makna baik dan buruk, serta dapat mendorongnya untuk melakuakan kebaikan dan keburukan. Di sini antara lain terlihat perbedaan pengertian kata ini menurut alqur'an dengan terminologi kaum sufi, menyatakan bahwa nafs dalam pengertian sufi adalah sesuatu yang melahirkan sifat tercela dengan prilaku buruk. Pengertian kaum sufi tentang nafs ini sama dengan yang terdapat dalam kamus umum bahasa Indonesia yang antara lain menjelaskan bahwa nafs adalah dorongan hati yang kuat untuk berbuat yang kurang baik.

Selanjunya Qurais Shihab mengatakan, walaupun Al-Qur'an menegaskan bahwa nafs berpotensi positif dan negatif, namun diperoleh pula isyarat bahwa pada hakikatnya potensi positif manusia lebih kuat dari pada potensi negatifnya, hanya saja daya tarik keburukan lebih kuat dari pada daya tarik kebaikan.

Sifat-sifat yang cenderung kepada keburukan yang ada pada manusia ini antara lain berlaku dzalim (aniaya), dalam kedaan susah payah (fikabad), suka melampaui batas (anid), sombong (kubbar), ingkar dan sebagainya. Karena itu manusia dituntut agar memelihara kesucian nafs, dan tidak mengotorinya.Untuk menjaga kesucian nafs ini manusia harus selalu 


\section{Jurnal Asy-Syukriyyah}

mendekatkan diri pada tuhan dengan bimbingan agama, dan disinilah letaknya kebutuhan manusia terhadap agama.

Dalam literatur teologi Islam misalnya kita jumpai pandangan kaum mu'tazilah yang rasionalis, karena banyak mendahulukan pendapat akal dalam memperkuat argumentasinya dari pada mendapat wahyu.Namun demikian mereka sepakat bahwa manusia dengan akalnya memiliki kelemahan.Akal memang dapat mengetahui yang baik dan yang buruk, tetapi tidak semua yang baik dan buruk dapat diketahui akal.

Dalam hubungan inilah, maka kaum mu'tazilah mewajibkan pada tuhan agar menurunkan wahyu dengan tujuan agar kekuarangan yang dimiliki akal dapat dilengkapi dengan informasi yang dating dari wahyu (agama).Dengan demikian, mu'tazilah secara tidak langsung memandang bahwa manusia memerlukan wahyu. ${ }^{17}$

3) Tantangan Manusia.

Faktor lain yang menyebabkan manusia memerlukan agama adalah karena manusia dalam kehidupannya senantiasa mengahadapi berbagai tantangan, baik yang datang dari dalam maupun dari luar. Tantangan dari dalam dapat berupa dorongan hawa nafsu dan bisikan setan.

Sedangkan tantangan dari luar dapat berupa rekayasa dan upaya-upaya yang dilakukan manusia yang secara sengaja berupaya ingin memalingkan manusia dari tuhan. Mereka dengan rela mengeluarkan biaya, tenaga, dan pikiran yang dimanifestasikan dalam berbagai bentuk kebudayaan yang di dalamnya mengandung misi menjauhkan manusia dari Tuhan.

Orang-orang kafir itu sengaja mengeluarkan biaya yang tidak sedikit untuk mereka gunakan agar orang mengikuti keinginannya. Berbagai bentuk budaya, hiburan, abat-obat terlarang dan lain sebagainya dibuat dengan sengaja. Untuk itu maka upaya mengatasi dan membentengi manusia adalah dengan mengajar mereka agar taat dan sadar dalam menjalankan agama.Godaan

\footnotetext{
${ }^{17}$ Abuddin Nata, Manajemen Pendidikan, (Jakarta: Prenada Media.2003). Hal 43
} 


\section{Jurnal Asy-Syukriyyah}

tantangan hidup demikian itu, saat ini semakin meningkatkan, sehingga upaya menumbuhkan kesadaran beragama sangatlah penting. ${ }^{18}$

Dari paparan di atas, maka kita sebagai manusia di muka bumi ini, dengan tanpa adanya agama pada diri kita mungkin kita akan hidup tak ubahnya seperti binatang. Manusia akan dengan gampangnya menghalalkan segala cara untuk kenikmatan sejenak, bahkan mungkin lebih dari pada itu, manusia akan hidup tak ubahnya seperti binatang yang hidup tanpa aturan yang jelas.

Disinilah kenapa kita harus menanamkan kesadaran beragama pada anak didik kita sedini mungkin, karena dengan kesadaran agama yang cukup tinggi, anak didik akan terbiasa menjalankan perintah Allah dan menjauhi segala larangan-Nya.

Istilah kesadaran beragama berasal atau terdiri dari kata kesadaran dan beragama. Untuk mengetahui lebih jauh tentang pengertian kedua istilah tersebut dapat penulis uraikan sebagai berikut:

Dalam kamus besar bahasa Indonesia, istilah kesadaran diartikan sebagai "keinsafan, kedaan mengerti".Kemudian kata beragama berasal dari kata agama yang berarti "kedudukan dan penghambaan terhadap sang Pencipta yang memerintah dan menjalankan urusan dunia". ${ }^{19}$

Dengan pengertian diatas penulis menyimpulkan bahwa perilaku Akhlaq adalah perilaku yang mampu menyelaraskan antara kehidupan di dunia dan kehidupan di akhirat.Dunia sebagai sarana akhirat atau ladang buat akhirat.

b. Tanda-Tanda Anak berakhlaqul karimah

Untuk mengklasifikasi perbuatan yang termasuk dalam Akhlaq karimah dalam ajaran agama Islam, antara lain:

1) Taat Menjalankan Perintah Allah

Seorang anak yang mulai sejak kecilnya dibiasakan kepada perbuatan-perbuatan baik yang diajarkan oleh agama dari orang tua dalamlingkungan keluarga kemudian ditambah lagi dengan pendidikan yang dijalankan disekolah secara baik, maka besar kemungkinan anak selalu

\footnotetext{
${ }^{18}$ Abuddin Nata, Manajemen Pendidikan, (Jakarta: Prenada Media. 2003). Hal 45

${ }^{19}$ Abdurrahman Nahlawi. Prinsip-prinsip dan metode Pendidikan Islam.(Bandung: Diponegoro.1992). Hal 52
} 


\section{Jurnal Asy-Syukriyyah}

berada pada garis kebenaran dengan mentaati segala perintah Allah dan menjauhi segala rangan-nya dalam kehidupan sehari-hari

Jika sejak masa kanak-kanaknya, anak tumbuh berkembang denga berpijak pada landasan iman kepada Allah dan terdidik untuk selalu takut, ingat, bersandar, meminta pertolongan dan berserahdiri pada-Nya, ia akan memiliki potensi dan respon secara lestingtif didalam menerima setiap keutamaan dan kemuliaan,disamping terbiasa melakukan akhlak mulia.

Sebab benteng pertahanan religius yang berakar pada hati sanubarinya, kebiasaan mengingat Allah telah dihayati dalam dirinya dan intropeksi diri yang telah menguasai seluruh pikiran dan perasaannya, telah memisahkan anak dari sifat-sifat negatif kebiasaan-kebiasaan dosa dan tradisi-tradisi Jahiliyah yang rusak. ${ }^{20}$

Bahkan penerimaannya terhadap setiap kebaikan akan menjadi salah satu kebiasaan dan kesenangannya terhadap keutamaan dan kemuliaan akan menjadi akhlak dan sifat yang paling menonjol.

2) Bersikap Jujur

Jujur berarti menempatkan sesuatu pada tempat yang selayaknya sesuai dengan tuntutan.Jujur merupakan sikap terpuji dan kunci sukses dalam pergaulan. Tidak diragukan lagi bahwa semua orang menuntut adanya sifat jujur, baik pada dirinya sendiri maupun pada orang lain. Apabila sifat jujur ini tidak diwujudkan pada diri seseorang, maka sulitlah sifat-sifat terpuji lainnya dapat dicapai.Orang yang jujur di senangi orang banyak.Bahkan orang yang jujur dengan mudah dapat meningkatkan martabatnya.

3) Menepati janji

Janji merupakan sikap terpuji yang harus dimiliki oleh anak.Janji antara manusia dengan Allah dan manusia dengan manusia harus ditepati. Janji kepada Allah harus kita tunaikan yaitu dengan menunaikan segala perintahNya dan menjauhi segala larangan-Nya,

${ }^{20}$ Abdullah Nashih Ulwan. 1993. Pedoman Pendidikan Anak dalam Islam.(Semarang: As-syifa': 1993). hal 174 
4) Bersikap Sabar

Sikap sabar merupakan suatu akhlak terpuji dan sebagai pengantar dalam kehidupanhal,sabar adalah ridha terhadap takdir Allah yang menimpanya atau senang terhadap segala apa yang dilakukan Allah atas dirinya. $^{21}$

Seorang anak yang memiliki pengetahuan agama yang tinggi, maka akan menempatkan kesabaran itu sebagai keharusan dalam kehidupan di dunia ini. Dan dalam setiap situasi apapun ia akan tetap baik, dan akan menghadapinya dengan ketenguhan dan kesabaran hati.

Jika kehidupan dunia sudah usai, maka bagi orang-orang yang sabarmemperoleh pahala yang besar dan balasan yang mulia,sehingga dapat melupakan mereka dari kesengsaraan yang mereka hadapi ketika berada di dunia.

5) Suka Membantu Orang Lain

Suka membantu orang lain merupakan sikap terpuji.Bagi sesama muslim seharusnya dapat menciptakan saling tolong menolong, meringankan beban dan tanggung jawab bersama.Jikamemiliki kelebihan, apakah itu harta, pikiran, dan tenaga, maka ia harus menyisihkan sebagian untuk membantu terutama sekali bagi yang lemah.Jika ada teman-temannya yang mengalami kesulitan, maka bantulah mereka, apakah melalui harta, pikiran, maupun tenaga.

Kesadaran bahwa manusia dalam hidup ini membutuhkan manusia lainnya menimbulkan perasaan bahwa setiap pribadi manusia terpanggil hatinya untuk melakukan apa yang terbaik bagi orang lain. Islam mengajarkan bahwa manusia yang paling baik adalah manusia yang paling banyak mendatangkan kebaikan kepada orang lain. Menurut sebuah hadist yang diriwayatkan oleh Qadla'ie dari Jabir, Rasulullah SAW pernah bersabda yang artinya : "Sebaik-baik manusia ialah orang yang banyak manfaatnya (kebaikannya) kepada manusia lainnya".

${ }^{21}$ Ahmad Daudi. Kuliah Ilmu Tasawuf, (Jakarta: PT Bulan Bintang.1998) Hal 59 
Kesadaran untuk berbuat baik sebanyak mungkin kepada orang lain ini melahirkan sikap dasar untuk mewujudkan keselarasan, keserasian dan keseimbangan dalam hubungannya antar manusia, baik pribadi maupun masyarakat lingkungannya.

Pada hakekatnya orang yang berbuat baik atau berbuat jahat terhadap orang lain adalah untuk dirinya sendiri. Mengapa orang lain senang berbuat baik kepada kita, karena kita telah berbuat baik kepada orang lain itu.

Ketinggian budi pekerti atau akhlak yang terdapat pada seseorang menjadikannya dapat melaksanakan kewajiban dan pekerjaan dengan baik dan sempurna, sehingga menjadikan orang tersebut hidup bahagia.Sebaliknya apabila manusia buruk akhlaknya, kasar tabiatnya, buruk buruk prasangkanya pada orang lain, maka hal itu sebagai pertanda bahwa orang itu hidup resah sepanjang hidupnya karena ketiadaan keserasian dan keharmonisan dalam pergaulannya sesama manusia lainnya.

Pelajaran akhlak bertujuan mengetahui perbedaan-perbedaan perangai manusia yang baik dan yang buruk agar manusia dapat memegang teguh sifat-sifat yang baik dan menjauhkan diri dari sifat-sifat yang jahat sehingga terciptalah tat tertib dalam pergaulan di masyarakat, di mana tidak ada benci membenci. Oleh karena itu pelajaran akhlak bertujuan hendak mendudukkan manusia sebagai makhluk yang tinggi dan sempurna serta membedakannya dengan makhluk-makhluk lainnya.Akhlak bertujuan menjadikan manusia orang yang berkelakuan baik terhadap Tuhan, manusia dan lingkungan.

Dari uraian di atas dapat disimpulkan bahwa pendidikan Akhlaq yang diterima oleh seorang siswa dari guru agamanya dapat menumbuhkan prilaku baik, ketaatan dirinya akan agamanya dalam perkembangan prilakunya. Dengan demikian berarti pendidikan agama Islam yang pernah diterima oleh siswa dapat mempengaruhi terhadap kesadaran beragama siswa tersebut.

d. Faktor-faktor yang Mempengaruhi Akhlaq Karimah

Akhlaq Karimah bagi siswa merupakan dambaan bagi setiap orang, baik orang tua siswa itu sendiri, masyarakat maupun guru sebagai orang yang bertanggung jawab terhadap pendidikan siswa yang telah diserahi amanat dan 
tanggung jawab dari para orang tua siswa. Oleh karena kesadaran agama memegang peranan penting dalam kehidupan siswa, maka hal itu perlu diupayakan secara baik oleh guru agar dapat tertanam pada diri siswa, yaitu melaksanakan perintah Allah dan menjauhi segala larangan-Nya.

Namun demikian, meskipun guru telah berusaha untuk mewujudkan siswa menjadi orang yang memiliki kesadaran tinggi dalam melaksanakan ajaran Islam, tetapi kadang kala usaha guru itu menemui hambatan-hambatan atau kendalakendala, sehingga tujuan mewujudkan siswa yang memiliki kesadaran tinggi dalam melaksanakan ajaran Islam tidak tercapai sesuai yang diharapkan. Hal itu disebabkan karena pada hakekatnya kesadaran beragama siswa itu sendiri dipengaruhi oleh banyak faktor.

Adapun faktor-faktor yang mempengaruhi kesadaran bergama menurut Hamzah Ya'kub adalah sebagai berikut:

\section{1) Faktor Dari Dalam}

yaitu segala faktor yang berasal dari siswa itu sendiri, seperti kematangan, perhatian, minat dan motivasi. Bila siswa memiliki kematangan, perhatian, minat dan motivasi yang baik dalam belajar pendidikan agama Islam, maka akan memungkinkan tumbuh dan berkembangnya kesadaran siswa dalam melaksnakan ajaran Islam secara baik pula. Sebaliknya bila siswa tidak memiliki kematangan, perhatian, minat, dan motivasi yang baik dalam belajar pendidikan agama Islam, maka kesadaran beragamapun tidak akan tumbuh dan berkembang dengan baik pada diri siswa. Kecendrungan siswa melalaikannya dalam melaksnakan ajaran agama Islam.

2) Faktor dari luar, yaitu segala faktor yang berasal dari luar diri siswa, seperti lingkungan keluarga, lingkungan sekolah dan lingkungan masyarakat. Ketiga lingkungan tersebut besar pengaruhnya terhadap kesadaran beragama siswa. ${ }^{22}$

Lingkungan keluarga yang merupakan lingkungan pertama yang dikenal anak, bila tercipta dalam suasana beragama, dalam arti orang tua taat menjalankan perintah agama serta membiasakan anak pada perbuatanperbuatan yang diajarkan agama, maka anakpun akan menjadi orang yang taat

${ }^{22}$ Hamzah Ya'kup. Etika Islam. (Bandung: Neponegoro.1991). Hal 57 


\section{Jurnal Asy-Syukriyyah}

dalam melaksnakan ajaran agama. Dalam kontek ini M. Thalib mengemukakan bahwa "tindakan orang tua yang melatih anaknya membiasakan menjalankan perintah tuhan, ketaatan orang tua kepada agama serta memberi bimbingan dan pengawasan dengan rasa sabar penuh kasih sayang, maka anaknyapun akan taat menjalankan perintah agama, sehingga menjadi manusia yang baik dan mempunyai kepribadian muslim"

Demikian juga sebaliknya, bila anak-anak tidak dilatih, dibiasakan dan dibina dengan nilai-nilai ajaran agama, dan orang tua itu sendiri tidak taat menjalankan perintah agama, maka anaknyapun akan jauh dari nilai-nilai ajaran agama, dalam arti tidak taat menjalankan perintah agama.

Lingkungan sekolah yang merupakan lingkungan kedua dikenal anak setelah lingkungan keluarga, juga mempunyai pengaruh yang besar terhadap kesadaran beragama anak. Bila di sekolah anak dilatih dan dibiasakan mengerjakan perintah agama, maka hal itu akan menanamkan pula terhadap kesadaran anak dalam melaksanakan ajaran agama. Demikian sebaliknya, bila di sekolah anak tidak dilatih dan dibiasakan pada ajaran Islam, dan guru hanya mengajarkan materi pendidikan agama sebatas konsep atau teori-teori saja, maka sulit untuk mewujudkan anak didik yang memiliki kesadaran tinggi dalam melaksanakan ajaran agama.

Lingkungan ketiga yaitu lingkungan masyarakat yang juga memiliki pengaruh besar terhadap kesadaran beragama anak. Bila lingkungan masyarakat terdiri dari lingkungan yang beragama, dalam arti taat menjalankan perintah agama, kecendrungan itu akan mempengaruhi pula terhadap tertanamnya kesadaran anak dalam melaksanakan ajaran agama. Namun sebaliknya bila lingkungan masyarakat terdiri dari lingkungan yang kacau, sering terjadi keributan, perjudian, dan jauh dari nilai-nilai ajaran Islam, maka cendrung anak akan melakukannya sebagaimana yang dilakukan oleh masyarakat lingkungannya.

Berbicara pada tatanan akhlak tentu tidak dapat dipisahkan dengan manusia sebagai sosok ciptaan Allah yang sangat sempurna, akhlak adalah mutiara hidup yang membedakan makhluk manusia dengan makhluk hewani, 
akhlak sangatlah urgen bagi manusia baik dalam kehidupan perseorangan maupun dalam kehidupan keluarga dan masyarakat, manusia tanpa akhlak, adalah manusia yang telah 'membinatang' sangat berbahaya, ia akan lebuh jahat dan lebih buas dari pada binatang buas.

Segala tindakan dan perbuatan manusia memiliki corak yang berbeda antara satu dengan yang lainnya, hal ini "pada dasarnya merupakan akibat adanya pengaruh dari dalam diri manusia (insting) dan motivasi yang dipengaruhi dari luar dirinya. Berikut akan dibahas faktor-faktor lain yang mempengaruhi akhlak.

a. Insting (naluri)

Aneka corak refleksi sikap, tindakan dan perbuatan manusia dimotivasi oleh potensi kehendak dimotori oleh insting seseorang.Insting (naluri) merupakan seperangkat tabiat yang dibawa masing-masing manusia sejak lahir. $^{23}$

Insting ini berfungsi sebagai motivator dan penggerak yang mendorong lahirnya tingkah laku manusia, seperti naluri makan, naluri berjodoh, naluri keibu bapakan, naluri perjuangan, dan naluri bertuhan, naluri ingin tahu dan memberi tahu naluri takut dan sebagainya.

b. Adat atau Kebiasaan

Menurut Zihri dalam zahirudin "Perbuatan manusia, apabila dikerjakan berulang-ulang sehingga menjadi mudah melakukannya, itu dinamakan adat kebiasaan". ${ }^{24}$

Dengan demikian, dapat dinyatakan bahwa adat taua kebiasaan adalah setiap tindakan atau perbuatan seseorang yang dilakukan secara berulangulang dalam bentuk yang sama sehingga menjadi kebiasaan, seperti makan, tidur, berpakaian dan lain sebagainya.

Pada perkembangan selanjutnya suatu perbuatan yang dilakukan berulangulang dan telah menjadi kebiasaan, akan dikerjakan dalam waktu yang singkat, menghemat waktu dan perhatian, seperti halnya si A yang sudah

${ }^{23}$ Zahruddin. Pengantar studi akhlak, (Jakarta: PT. Raja Grafindo Persada. 2004), Cet, ke-1, hal. 57

${ }^{24}$ Zahruddin. Pengantar studi akhlak, (Jakarta: PT. Raja Grafindo Persada. 2004. Cet, ke-1, hal, 63 


\section{Jurnal Asy-Syukriyyah}

pandai menulis, dengan sedikit waktu dan perhatian akan menghasilkan Tulisan yang banyak.

c. Wirotsah (keturunan)

Dalam pembahasan ini akan menilai keturunan (wirotsah) dari pendekatan ilmu pedagogis. Dalam imu pendidikan, kita mengenal adanya perbedaan antara aliran nativisme vyang dipelopori oleh Schopenhaur dengan aliran empirisme yang dipelopori oleh Jhon lock.

Aliran nativisme berpendapat bahwa perkembangan jiwa seseorang itu ditentukan oleh bakat yang dibawa sejak lahir, aliran ini menyatakan pendidikan yang diterima tidak bisa mempengaruhi perkembangan jiwa seseorang. Sedangkan menurut aliran empirisme dalam teori tabula rasa, berpendapat bahwa perkembangan jiwa anak itu mutlak ditentukan oleh pendidikan atau lingkungan. Kemudian timbullah teor konvergensi, yang bersifat kompromi atas kedua teori tersebut, teori ini berpendapat bahwa 'dasar' dan 'ajar' secara bersama membina perkembangan jiwa manusia.

Sehubungan dengan hal tersebut, Zahirudin menyatakan "bahwa sifat-sifat asasi orang tuanya, terkadang anak itu mewarisi sebagian besar salah satu sifat orang tuanya".

Namun demikian, sifat yang diturunkan orang tua terhadap anaknya bukanlah sifat yang dimiliki anak itu yang tumbuh dan berkembang dengan matang karena dipengaruhi oleh lingkungan, adat ataupun pendidikan, melainkan merupakan sifat-sifat bawaan sejak lahir.Sifat-sifat yang diturunkan ini pada garis besarnya adalah jasmaniah, seperti postur tubuh, warna kulit dan lain sebagainya.Serta sifat rohaniah seperti sifat penakut, pemberani, cerdas, sabar dan lain sebagainya.

Dengan demikian dapat ditegaskan bahwa faktor keturunan secara langsung atau tidak langsung sangat mempengaruhi pembentukan sikap dantngkah laku seseorang. ${ }^{25}$

${ }^{25}$ Zahruddin. Pengantar studi akhlak, (Jakarta: PT. Raja Grafindo Persada. 2004). Cet, ke-1, hal, 68 
d. Milieu (lingkungan)

Salah satu faktor yang mempengaruhi prilaku seseorang adalah lingkungan di mana seseorang berada, yang dimaksud lingkungan di sini adalah segala apa yang melingkupi manusia, yang terdiri dari lingkungan alam dan lingkungan pergaulan.

1) Lingkungan Alam

Alam yang melingkupi manusia merupakan factor yang mempengaruhi dan menentukan tingkah laku seseorang.Lingkungan alam ini dapat mematangkan pertumbuhanbakat yang dibawa seseorang sejak lahir, dalam artian, jika kondisi alamnya jelek hal itu merupakan perintang dalam mematangkan bakat seseorang.

Sehingga hanya mampu berbuat sesuai kondisi yang ada. Sebaliknya jia kondisi alam itu baik, kemungkinan seseorang akan dapat berbuat lebih mudah dalam mengembangkan bakat yang ia bawa sejak lahir.

Sehubungan dengan hal ini Zahirudin menyatakan bahwa "Kondisi alam ini ikut mencetak akhlak manusia-manusia yang dipangkunya.

2). Lingkungan Pergaulan

Sebagai makhluk sosial, manusia membutuhkan orang lain untuk menemani dan menjalani hidup bersamanya itulah sebabnya manusia akan saling mempengaruhi antara yang satu dengan yang lainnya dalam pikiran, sifat, dan tingkah laku, baik pergaulan itu dalam lingkungan sekolah maupun dalam lingkungan masyarakat.

Demikianlah beberapa faktor yang mempengaruhi prilaku seseorang dalam perkembangan hidupnya, yang pada dasarnya terdiri dari faktor diri manusia (insting) dan warosfah serta faktor yang disuplai dari luar diri manusia (adat atau kebiasaan, milieu atau lingkungan).

\section{Proses Pembentukan Akhlaqul Karimah}

Meskipun kepribadian seseorang itu relatif konstan, namun dalam kenyataannya sering ditemukan bahwa perubahan kepribadian dapat dan mungkin terjadi, terutama dipengaruhi oleh faktor lingkungan dari pada faktor fisik. Erikson mengemukakan tahapan perkembangan kepribadian dengan kecenderungan yang berbeda antara lain: 


\section{Jurnal Asy-Syukriyyah}

1. Masa bayi (infancy) ditandai adanya kecenderungan trust - mistrust. Perilaku bayi didasari oleh dorongan mempercayai atau tidak mempercayai orang-orang di sekitarnya. Dia sepenuhnya mempercayai orang tuanya, tetapi orang yang dianggap asing dia tidak akan mempercayainya. Oleh karena itu kadang-kadang bayi menangis bila di pangku oleh orang yang tidak dikenalnya.Ia bukan saja tidak percaya kepada orang-orang yang asing tetapi juga kepada benda asing, tempat asing, suara asing, perlakuan asing dan sebagainya. Kalau menghadapi situasi-situasi tersebut seringkali bayi menangis.

2. Masa kanak-kanak awal (early childhood) ditandai adanya kecenderungan autonomy shame, doubt. Pada masa ini sampai batas-batas tertentu anak sudah bisa berdiri sendiri, dalam arti duduk, berdiri, berjalan, bermain, minum dari botol sendiri tanpa ditolong oleh orang tuanya, tetapi di pihak lain dia telah mulai memiliki rasa malu dan keraguan dalam berbuat, sehingga seringkali minta pertolongan atau persetujuan dari orang tuanya.

3. Masa pra sekolah (Preschool Age) ditandai adanya kecenderungan initiative - guilty. Pada masa ini anak telah memiliki beberapa kecakapan, dengan kecakapan-kecakapan tersebut dia terdorong melakukan beberapa kegiatan, tetapi karena kemampuan anak tersebut masih terbatas adakalanya dia mengalami kegagalan.Kegagalan-kegagalan tersebut menyebabkan dia memiliki perasaan bersalah, dan untuk sementara waktu dia tidak mau berinisatif atau berbuat.

4. Masa Sekolah (School Age) ditandai adanya kecenderungan industry-inferiority. Sebagai kelanjutan dari perkembangan tahap sebelumnya, pada masa ini anak sangat aktif mempelajari apa saja yang ada di lingkungannya. Dorongan untuk mengetahui dan berbuat terhadap lingkungannya sangat besar, tetapi di pihak lain karena keterbatasan-keterbatasan kemampuan dan pengetahuannya kadang-kadang dia menghadapi kesukaran, hambatan bahkan kegagalan. Hambatan dan kegagalan ini dapat menyebabkan anak merasa rendah diri.

5. Masa Remaja (adolescence) ditandai adanya kecenderungan identity - Identity Confusion. Sebagai persiapan ke arah kedewasaan didukung pula oleh kemampuan dan kecakapan-kecakapan yang dimilikinya dia berusaha untuk membentuk dan memperlihatkan identitas diri, ciri-ciri yang khas dari dirinya. Dorongan membentuk dan memperlihatkan identitasdiri ini, pada para remaja sering sekali sangat ekstrim 
dan berlebihan, sehingga tidak jarang dipandang oleh lingkungannya sebagai penyimpangan atau kenakalan.Dorongan pembentukan identitas diri yang kuat di satu pihak, sering diimbangi oleh rasa setia kawan dan toleransi yang besar terhadap kelompok sebayanya.Di antara kelompok sebaya mereka mengadakan pembagian peran, dan seringkali mereka sangat patuh terhadap peran yang diberikan kepada masing-masing anggota.

6. Masa Dewasa Awal (Young adulthood) ditandai adanya kecenderungan intimacy isolation. Kalau pada masa sebelumnya, individu memiliki ikatan yang kuat dengan kelompok sebaya, namun pada masa ini ikatan kelompok sudah mulai longgar. Mereka sudah mulai selektif, dia membina hubungan yang intim hanya dengan orangorang tertentu yang sepaham.Jadi pada tahap ini timbul dorongan untuk membentuk hubungan yang intim dengan orang-orang tertentu, dan kurang akrab atau renggang dengan yang lainnya.

7. Masa Dewasa (Adulthood) ditandai adanya kecenderungan generativity-stagnation. Sesuai dengan namanya masa dewasa, pada tahap ini individu telah mencapai puncak dari perkembangan segala kemampuannya.Pengetahuannya cukup luas, kecakapannya cukup banyak, sehingga perkembangan individu sangat pesat. Meskipun pengetahuan dan kecakapan individu sangat luas, tetapi dia tidak mungkin dapat menguasai segala macam ilmu dan kecakapan, sehingga tetap pengetahuan dan kecakapannya terbatas. Untuk mengerjakan atau mencapai hal- hal tertentu ia mengalami hambatan.

8. Masa hari tua (Senescence) ditandai adanya kecenderungan ego integrity - despair. Pada masa ini individu telah memiliki kesatuan atau intregitas pribadi, semua yang telah dikaji dan didalaminya telah menjadi milik pribadinya.Pribadi yang telah mapan di satu pihak digoyahkan oleh usianya yang mendekati akhir. Mungkin ia masih memiliki beberapa keinginan atau tujuan yang akan dicapainya tetapi karena faktor usia, hal itu sedikit sekali kemungkinan untuk dapat dicapai. Dalam situasi ini individu merasa putus asa. Dorongan untuk terus berprestasi masih ada, tetapi pengikisan kemampuan karena usia seringkali mematahkan dorongan tersebut, sehingga keputusasaan acapkali menghantuinya 


\section{Jurnal Asy-Syukriyyah}

\section{Upaya-Upaya Meningkatkan Akhlaq Anak Pada Usia Dini}

Orang tua memiliki hak dan tanggung jawab penuh terhadap seorang anak, kebaikan di dunia akan bepengaruh terhadap kebaikan orang tua pula, dan sebaliknya. Pahala dan dosa seorang anak merupakan pahala dan dosa orang tua. Oleh karena itu, orang tua harus bahkan wajib membina dan mendidik anak untuk selalu melaksanakan perintah Allah, seperti shalat, sabar bersyukur, dan banyak hal lainnya. Hal ini sebagaimana firman Allah dalam Al-Qur'an Surat Al-Baqarah: 152-153:

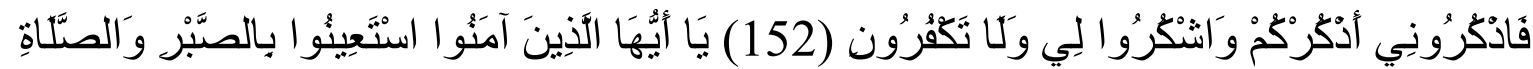

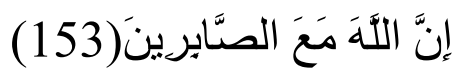

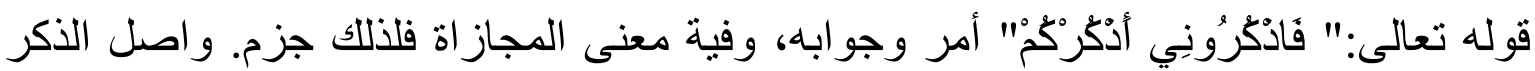

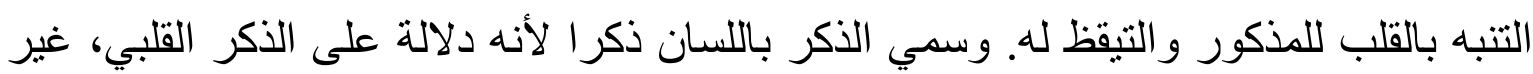
أنه لما كثر إطلاق الذكر على القول اللساني صار هو السابق للفهم. ومعنى الآية: اذكروني بالطاعة أذكركم بالثواب و المغفرة، قاله سعيد بن جبير. وقال أيضا: الذكر طاعة الله، فمن لم

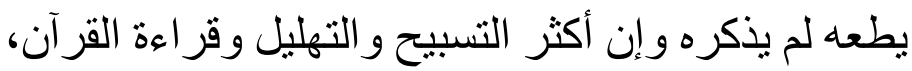

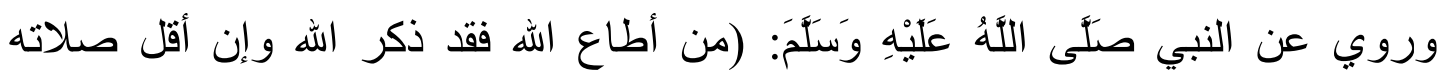
وصومه وصنيعه للخير ومن عصى الله فقد نسي الله و إن كثر صلاته وصومه وصنيعه للخير)، ذكره أبو عبد الله محمد بن خويز منداد في" أحكام القرآن" له. وقال أبو عثمان النهدي: إني واني

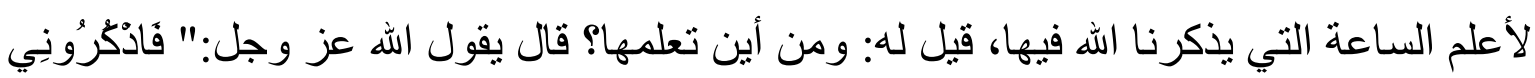
أذّكُرْكُ". وقال السدي: ليس من عبد يذكر الله إلا ذكره الله عز وجل، لا يذكره مؤمن إلا ذكره

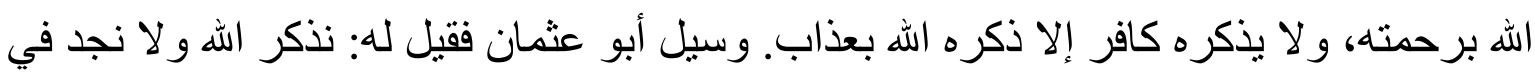
قلوبنا حلاوة؟ فقال: احمدوا الله تعالى على أن زين جارحة من جواركم بطاعته. وقال ذو ذالهره النون المصري رحمه الله: من ذكر الله تعالى ذكر ا على الحقيقة نسي في جنب دئ ذكره

Dari ayat diatas menunjukkan bahwa orang tua sebgai pendidik pertama dan utama dalam keluarga, memiliki pengaruh yang sangat besar dalam pembinaan dan peningkatan akhlak anak. Oleh karena itu, orang tua perlu melakukan upaya-upaya dalam peningkatan akhlak anak tersebut. 


\section{Jurnal Asy-Syukriyyah}

Adapun metode-metode yang dapat dilakukan orang tua dalam rangka meingkatkan akhlak anak, adalah sebagai berikut :

1. Mendidik dan Membimbing Anak

Sebagaimana telah dijelaskan di atas, bahwa orang tua merupakan pendidik pertama dan utama dalam keluarga.Dengan demikian maka keluarga berfungsi sebagai pembina, pengarah dan pengawas terhadap anak-anaknya ke jalan yang benar dan diridhai Allah SWT.Yang harus dipertanggung jawabkan dihadapan Allah nantu.

Mengingat akhlak anak banyak ditentukan oleh pendidikan, pengalaman dan latihan-latihan yang dilaluinya baik dalam keluarga maupun dalam lingkungan masyarakat, maka orang tua yang harus dilakukan adalah :

1). Memberikan nama yang baik

2). Memberi pelajaran dan pendidikan agama dan ilmu yang bermanfaat untuk dunia dan akhirat

3). Memelihara kesehatan jasmani dan rohani anak

4). Memberi nafkah yang halal dan baik

5). Tidak bertengkar di hadapan anak

6). Tidak menyerahkan bulat-bulat pendidikan anak-anaknya

7). Tidak membedakan dan memanjakan anak-anak

8). Memberi contoh teladan yang baik

9). Menjaga dan mengawasi pergaulan sehari-hari. ${ }^{26}$

Apabila sejak keccil anak dididik, dibimbing, dibina dan diawasi dengan baik oleh orang tua dalam kehidupannya, maka akan terjadi anak yang meiliki kepribadian yang sesuai dengan nilai-nilai agama yaitu beriman dan bertakwa kepada Allah, mengerjakan perbuatan-perbuatan terpuji dan menjauhi sebala perbuatan yang tercela.

${ }^{26}$ Taufikurrahman. Akidah Akhlak Madrasah Aliyah untuk Kelas X Semester Ganjil. (Jakarta : Kandepag. 2005). Cet. Ke-1, hal 52 


\section{Jurnal Asy-Syukriyyah}

2. Adanya Perhatian Orang Tua

Anak sebagai amanat Allah berarti bahwa anak secra hakikat adalah milik Allah dan hanya merupakan titipan kepada orang tua, oleh karena anak merupakan amanah Allah, maka merupakan suatu kewajiban bagi orang tua untuk menjaga, memelihara dan memperhatikan amanat tersebut agar tidak menyimpang dari jalan Allah, orang tua tidak boleh melalaikan amanat itu, karena hal yang demikian itu akan merugikan terhadaporang tua itu sendiri, sebagaimana firman Allah :

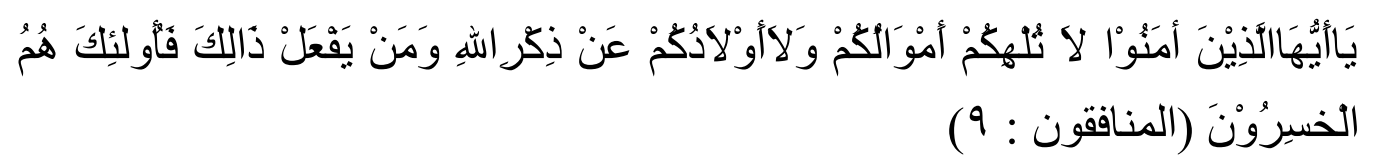

"Hai orang-orang yang beriman janganlah harta-hartamu dan anakanakmu melalaikan kamu dari mengingat Allah.Barang siapa yang berbuat demikian maka mereka itu orang-orang merugi" (QS. Al-Munafiqun, 63:9) ${ }^{27}$

3. Membiasakan Anak Pada Perbuatan-Perbuatan Baik

Membiasakan berarti melatih anak untuk melakukan perbuatan baik sesuai dengan nilia-nilia agama sehingga menjadi sikap kebiasaan yang benar-benar melekat dalam diri anak dan dipraktekkan dalam kehidupan sehari-hari.

Penanaman sikap kebiasaan oleh orang tua pada diri anak, kini sangat besar pengaruhnya terhadap pertumbuhan dan perkembangan jiwa anak.Untuk itu orang tua harus memusatkan perhatian pada pendidikan yang bersifat pembiasaan ini mulai anak memahami kehidupan.

Anak-anak amanat kedua orang tuanya dan hatunya yang suci adalah permata yang sangat mahal harganya, karena jika dibiasakan pada kebaikan dan

${ }^{27}$ Dalam Tafsier Al-Qurthuby dijelaskan;

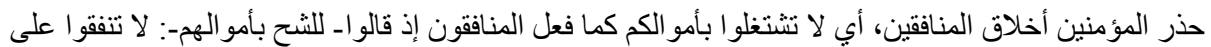

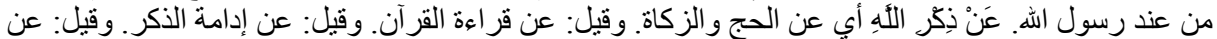

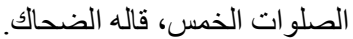

$$
\begin{aligned}
& \text { وقال الحسن: جميع الفر ائض، كأنه قال عن طاعة الله. وقيل: هو خطاب للمنافقين، أبي آمنتم بالقول فآمنو ا بالقلب. }
\end{aligned}
$$

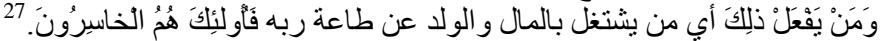


diajarkan kebaikan pada dirnya maka ia akan tumbuh pada kebaikan tersebut dan akan berbahagialah di dunia dan akhirat. ${ }^{28}$

Pendidikan dengan membiasakan ini merupakan pilar terkuat dalam membentuk dan membina kepribadian anak, serta merupakan metode efektif dalam membentuk iman nak dan meluruskan kahlaknya.

Dengan demikian, maka biasakanlah anak dengan mengerjakan perbuatanperbuatan yang baik dalam keluarga mulai dari cara berpakaian, makan dan minum, tidur, berbicara dengan orang tua dan perbuatan-perbuatan terpuji lainnya. Apabila menjumpai anak mengerjakan perbuatan mungkar, maka hendaknya orang tua memperingatinya, dan katakan kepada anak bahwa perbuatan tercela itu adalah dosa.

\section{Kesimpulan}

Pendidikan akhlaq adalah suatu proses menumbuhkembangkan potensi spiritual dan emosional anak dengan penanaman nilai-nilai agama Islam sejak dini. Proses yang dilakukan sejak dini sangatlah penting agar dapat tertanam derngan baik dan menjadi tabiat dalam kehidupan sehari-hari serta dapat berlangsung di masa-masa berikutnya.

Pendidikan akhlaq adalah suatu proses pembinaan, penanaman, dan pengajaran, pada manusia dengan tujuan menciptakan dan mensukeskan tujuan tertinggi agama Islam, yaitu kebahagiaan dua kampung (dunia dan akhirat), kesempurnaan jiwa masyarakat, mendapat keridlaan, keamanan, rahmat, dan mendapat kenikmatan yang telah dijanjikan oleh Allah SWT yang berlaku pada orang-orang yang baik dan bertaqwa.Karena akhlaq merupakan fondasi (dasar) yang utama dalam pembentukan pribadi manusia yang seutuhnya, maka pendidikan yang mengarah terbentuknya pribadi yang berakhlaq, merupakan hal yang pertama yang harus dilakukan, sebab akan melandasi kestabilan kepribadian manusia secara keseluruhan.

${ }^{28}$ Abdullah Nashih Ulwan. Pedoman Pendidikan Anak dalam Islam. (Semarang: As-syifa'. 1993) Cet. Ke-1, hal 62 


\section{Jurnal Asy-Syukriyyah}

Rasulullah SAW bersabda:

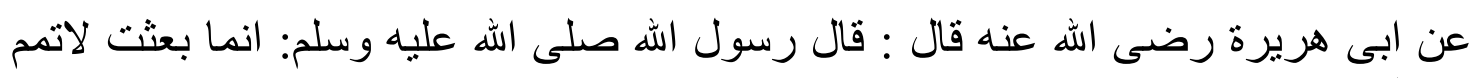

صالح الاخلاق (رو اه احمد) رداه

Dari Abu Hurairah r. a. Rasulullah saw telah bersabda : aku diutus hanyalah untuk menyempurnakan budi pekerti yang luhur (HR Ahmad).

Dengan memiliki akhlaq yang karimah maka seseorang akan dapat berhubungan dengan baik dengan sang pencipta, dapat diterima dalam setiap pergaulannya, juga melestarikan alam ciptaan Allah, oleh karena itu penanaman akhlaqul karimah perlu ditanamkan sejak dini pada anak.

Dalam diri manusia mempunyai tiga potensi, Yaitu potensi bernafsu (an-nafs albahimiyyah), potensi berani (an-nafs as-subuiyyat) dan potensi berfikir (an-nas annathiqiyah). Potensi bernafsu dan potensi berani berasal dari unsur materi sehingga akan hancur pada suatu saat, sedangkan potensi berfikir berasal dari ruh Tuhan sehingga bersifat kekal. Nilai-nilai pendidikan akhlaq yang harus ditanamkan kepada anak-anak bukan sekedar akhlaqul karimah, melainkan akhlaq madzmumah juga harus di sampaikan dan diajarkan kepada anak. Bila akhlaq yang buruk itu tidak di sampaikan kepada anak maka anak akan melakukan perbuatan yang tidak sesuai dan melanggar etika yang ada di masyarakat itu.

Oleh karena itu pendidikan Islam akan tegak lurus jika pendidikan nilai-nilai keagamaan yang diimplementasikan dengan perilaku Akhlaq karimah dalam kehidupan sehari-hari, dalam segala hal dan dalam segenap ruang dan waktu. Pendidikanlah yang akan mengantar manusia pada derajat insan kamil, sempurna secara aqliyah, ruhiyyahdan sempurna secara jasmaniyah.Pendidikan dapat kita tinjau dari dua sudut pandang.Pertama, dari sudut pandangan masyarakat, pendidikan merupakan pewarisan kebudayaan dari generasi tua ke generasi muda agar hidup masyarakat berkelanjutan. Atau dengan kata lain, masyarakat mempunyai nilai-nilai budaya islami yang ingin disalurkan dari generasi ke generasi agar identitas masyarakat madani tersebut tetap terpelihara. 


\section{DAFTAR PUSTAKA}

Ali, Daud, Muhammad, Pendidikan Agama Islam, (Jakarta: Rajagrafindo Persada, 2008) Ali, Zainuiddin, Pendidikan Agama Islam, (Jakarta: Bumi Aksara, 2007)

Asrohah, Hanun. Sejarah Pendidikan Islam. (Jakarta : PT. Logos Wacana Ilmu. 2001)

An-Nahlawi, Abdurrahman, "Pendidikan Islam di Rumah, Sekolah, dan Masyarakat". (Jakarta: Gema Insani.1998)

Abror, Abd Rahman. Psikologi Pendidikan. Cet IV. (Yogyakarta: Tiara Wacana Yogya. 1993)

Arifin. Hubungan Timbal Balik Pendidikan Agama di Lingkungan Sekolah dan Keluarga (sebagai pola pengembangan metodologi). (Jakarta:Metro Pos. 1975)

Azzet, Akhmad Muhaimin, Urgensi Pendidikan Karakter di Indonesia: Revitalisasi Pendidikan Karakter terhadap Keberhasilan Belajar dan Kemajuan Bangsa, (Jogjakarta: Ar-Ruzz Media, 2011)

Aqib, Zainal, Profesionalisme Guru Dalam Pembelajaran, (Surabaya: Insan Cendekia, 2002)

Arif, Armai, “Reformasi Pendidikan Islam”. (Ciputat: Ciputat Pres Group. 2005)

Arifi, M, “Ilmu Pendidikan Islam”. (Jakarta: Bumi Aksara. 1993)

Badan Penasehat Pembinaan dan Pelestarian Perkawinan (BP-4), 1993. Tuntunan Praktis Rumah Tangga Bahagia

Bachtiar, Wardi, Metodologi Penelitian Ilmu Dakwah, (Jakarta, Logos.1997)

Djiwandono, Sri Esti Wuryani, Psikologi Pendidikan Edisi Revisi, (Jakarta: Grasindo: 2009), cet- 15

Djamarah, Bahri, Saiful, Guru dan Anak didik dalam perspektif edukatif, (Jakarta: Rineka Cipta, 2005)

Djamarah, Syaiful Bari. Psikologi Belajar. Bandung:Remaja Rosdakarya

Dipartemen Agama RI, “Metodologi Pendidikan Agama Islam”. (Jakarta: Depag. 2002) 


\section{Jurnal Asy-Syukriyyah}

Dimyati dan Mudjiono, Belajar Dan Pembelajaran (Jakarta, Departemen Pendidikan dan Kebudayaan bekerjasama dengan Rineka Cipta, 2009)

Hasyim, Umar. 1983. Cara Mendidik Anak dalam Islam, Surabaya: Bina Ilmu

Haidar, Putra, Daulay, Pendidikan Islam, (Jakarta: Reneka. 2007)

Hamalik Oemar, Perencanaan Pengajaran Berdasarkan Pendekatan Sistem (Jakarta, PT Bumi Aksara, 2002)

Jaya, Yahya, “Bimbingan Konseling Agama Islam” (Angkasa Raya. 2004)

Jauhari, Idris, Pengantar Ilmu Jiwa Umum, (Prenduan, Al-Amien Printing.1996)

Mahyuddin, Kuliah Akhlaq Tasawwuf (Jakarta: Kalam Mulia, 2003), cet-5.2010)

Marhijanto, Kholilah, Menciptakan Keluarga Sakinah, Gersik: Bintang Pelajar.

Muslihah, Eneng, “Ilmu Pendidikan Islam” (Jakarta: Diadit Media. 2011)

Mustofa. A, “Akhlaq Tasawuf” (Bandung: Pustaka Setia. 1997)

Munandir, 1983, Pokok-pokok Pikiran tentang Pengajaran dan Konseling Agama da Usaha Pengembangan Penyuhan Masyarakat, (Surabaya.

Mansur, Hasan. Metode Islam dalam Mendidik. (Jakarta:Mustaqim. 2002)

Nasution, Noehi. Psikologi Pendidikan. (Jakarta: Universitas Terbuka. 1982)

Nata, Abudin, “Paradigma Pendidikan Islam”. (Jakarta: Gramedia. 2001)

Nata, Abuddin, Tafsir Ayat-Ayat Pendidikan (Tafsir Al-Ayat Al-Tarbawiy) (Jakarta, PT RajaGrafindo, 2002)

Purwanto, Ngalim. Ilmu Pendidikan Teoritis dan Praktis. (Bandung:Remaja Rosda Karya. 1994) 